\title{
王子製紙(株)日南工場
}

\section{-Nichinan Mill, Oji Paper Co., Ltd.-}

\section{1. 日南工場のあゆみ}

ここに紹介する日南工場は王子製紙 6 工場の内で第 一級の品質を誇る高級印刷用紙「サンフラワー」に代 表される上質紙を中心に情報産業用紙，特殊紙等多彩 な紙の生産を受け持つ紙の一貫生産工場である。

当工場は昭和 13 年 (1938 年) 10 月, 日本パルプ工 業侏飫肥工場として操業を開始し満 54 年を迎えた。そ の間に町村合併による日南市の誕生に伴い, 昭和 25 年 に工場名を日南工場と改称し, 昭和 54 年 3 月 1 日に王 子製紙橉日南工場となった。

当工場の歴史は大きく分けて SP 時代（人絹パルプ 時代）と紙化時代とに分けられる。わが国人絹工業が 世界第 1 位の生産を挙げるようになった昭和 12 年か ら 13 年にかけて,いわゆるパルプ 5 社の仲間として日 南工場も建設され, 当時はエゾマツ, トドマツ等の北 洋材はすでに逼迫していたので，当工場もこの地方に 多い杉の間伐材を原料として人絹パルプ (DSP) を製 造すべく $20,000 \mathrm{t} /$ 年の計画で発足した。

戦後は爆撃を免れた $7.5 \mathrm{t}$ 木鉒 1 基と 88 ” ペーパー マシン 1 台とから復興活動に入り，KP法へ転換する までDSP と BSP の 2 系列のパルプと洋紙の生産を 行い,この間の中心的製品はDSP で当工場の歴史に とって第 1 世代の SP 時代を構成している。

松材の逼迫から広葉樹の利用を図るべく, 35 年から 36 年にかけて SP 法から KP 法への転換を行い, 合計 $96,000 \mathrm{t} /$ 年のパルプ.場に転換拡張した。その後パル プの紙化路線を走り，3号ペーパーマシンから 8 号 ペーパーマシンの增設と続き, 現在は洋紙の生産能力 $250,000 \mathrm{t} /$ 年の完全な紙丁場として一新している。

また, 紙の高付加価值化を目標に昭和 47 年には加工 部を設置して特殊加工紙の生産を開始し，平成元年に は最新鋭の 4 品コーターも完成して, 現在 4 台のコー ターで情報関連特殊塗工紙を生産している。近年, 紙 をべースにした製品に限らず，合成紙べースの感熱記 録紙などの分野にも進出し，時代をリードする紙の先 端丁場として発展している（表 1 ）。

\section{2. 工場立地}

・日南市

当工場の立地する日南市は宮崎県南部の海岸沿いに 位置し, 後背に南九州の豊富な広葉樹資源を控え，表 には天然の良港油津港を据え，市の中央には水量豊富 な広渡川と酒谷川を抱えた人口約 5 万人の地方都市で ある。

市は南北 $90 \mathrm{~km}$ に及ぶ『太陽と緑のロードパーク』 国定公園日南海岸のほぼ中央に位置し，市の西には伊

表 1 日南工場のあゆみ

\begin{tabular}{|c|c|}
\hline 昭和 13 年 10 月 & $\begin{array}{l}\text { 日本パルプ工業(侏)飫肥工場として } \\
\text { 竣工, 操業開始 }\end{array}$ \\
\hline 昭和 21 年 4 月 & $\begin{array}{l}88 \text { インチ抄紙機稼働 } \\
\qquad(\text { 昭和 } 55 \text { 年撤去) }\end{array}$ \\
\hline 昭和 25 年 1 月 & 日南市誕生に伴い日南工場と改称 \\
\hline 昭和 26 年 5 月 & 1 号抄紙機稼働（昭和 60 年撤去） \\
\hline 昭和 35 年 4 月 & $\begin{array}{l}\text { パルプ生産をクラフト法に転換 } \\
3 \text { 号抄紙機稼働 }\end{array}$ \\
\hline 昭和 47 年 8 月 & 加工部発足 \\
\hline 昭和 47 年 9 月 & 1 号コーター稼働 \\
\hline 昭和 52 年 7 月 & 志布志チップ荷役設備完成 \\
\hline 昭和 52 年 12 月 & 8 号抄機稼働 \\
\hline 昭和 54 年 3 月 & $\begin{array}{l}\text { 合併により王子製紙(侏)日南工場と } \\
\text { なる }\end{array}$ \\
\hline 昭和 54 年 11 月 & 連続蒸解釜稼働 \\
\hline 昭和 57 年 6 月 & 3 号コーター稼働 \\
\hline 昭和 60 年 10 月 & 1 号回収ボイラー稼働 \\
\hline 昭和 62 年 10 月 & ラミネーター営業運転 \\
\hline 平成元年 8 月 & 4 号コータ一稼働 \\
\hline 平成 3 年 12 月 & 酸素晒設備稼働 \\
\hline
\end{tabular}




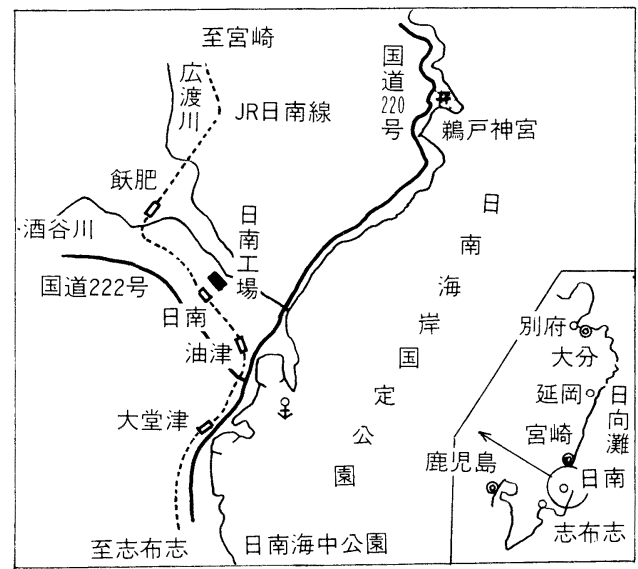

図 1 工場立地困

東藩 5 万 1 千石の城下町が往時のたたずまいを残し (重要伝統的建造物保存地区指定), その奥には飫肥杉 刀美林が続く観光の街である。工場は市のほぼ中心に 位置している(図 1)。

・ 油津港

巾の東には天然の良港として昔から栄えた油津港 (重姴港湾)があり, 当工場を含めて市の商工業の中心 をなしている。油津港は木材製品（飫肥杉による弁甲 材）農産物，水産物等を取扱い当工場の資材，製品の 利用度も高い。現在 $5,000 \mathrm{t}$ バースまでであるが, 35,000 七バースおよび公共埠頭 14 万 $\mathrm{m}^{2}$ の建設が目 下進行中であり, 将来の当工場の有力な立関と期待さ れている。工場から油津港までは約 $4 \mathrm{~km}$ あり, 現在港 には当社の製品倉庫等が存在する。

- 用水，排水

市の中央を流れる広渡川と酒谷川から合計 14 万 4 千 $\mathrm{m}^{3} /$ 日 (取水権)の工業用水を取水し, 排水は暗渠に よって全量 $3.2 \mathrm{~km}$ 先の日向灘に放流している。

当工場では昭和 13 年の工場建設時から暗渠による 海岸放流方式を採用しており, 昭和 40 年に 1 本増強し 今日に至っている。

・陸海交通

日南一宫崎 $46 \mathrm{~km}$ は国道 220 号線で結ばれている。 また油津港による海上輸送と, 鹿児島県志布志港（日 湳工場より $46 \mathrm{~km})$ の水哚 $10 \mathrm{~m}$ の外貿バースに隣接 してチップヤードと荷揚設備を設け外材チップの受入 れを行っている。また製品については油津港からの貨 物船による出荷が主体であるが, 一部志布志港, 宮崎 港及び日向市の工業港細島港（日南工場より $100 \mathrm{~km}$ ) から阪神，京浜へのカーフェリーによる製品出荷を 行っている。

\section{3. 工 場 概 要}

日南工場の特徴はクラフトパルプ・卜級紙の一貫工 場である事と, 更に感熱記録紙等の高付加価値塗工紙, 及びカラー印画紙用原紙を生産している事である。

原木はオール Lチップで，Lチップの約 $45 \%$ は国内 材, 約 55\%が外国材である。パルプ工程は BKP 660 t/ 日の生産能力を有し, 力ミヤ式連続蒸解鉒で蒸解し, $\mathrm{O}_{2}$ 晒設備と $\mathrm{CEHD} の 4$ 段漂白設備で漂白する。パル プは全量 5 台の抄紙機で紙化され，一部は更に 4 台の コーターで高付加価值の特殊涂亡紙へ加 Iされる。

蒸気発生設備として 3 基の回収ボイラー，1基のオ イルボイラー，1基のバークボイラーを有している。 発電設備としては 4 基のタービンを備え, 約 $85 \%$ の電 力を自家発電で賄っている。

環境保全設備として排水関係に活性汗泥，凝集沈澱 設備を, 大気関係に電気集じん器, スクラバー, 排煙 脱硫設備を，系気関係に臭気排水ストリッパー等を備 えており，環境規制值を十分爰守出来る体制を整えて いる。

工場敷地は 48 万 5 千 $\mathrm{m}^{2}$, 従業員 562 名, 組織は 8 部 2 室制で操業部門は 4 組 3 交代制を採用している（表 2, 図 2)。

\section{4. 主要設備}

\section{1 チップ受払工程}

当工場の原木使用量は年間 35 ノ BDT で, 使用樹種 はオール L チップであり，その内訳は大略表 3 の通り である。

表 2 日南工場概要

\begin{tabular}{|c|c|c|}
\hline \multirow{2}{*}{ 土 } & \multirow{2}{*}{$\begin{array}{l}\text { 工場構内面積 } \\
\text { 社宅面積 }\end{array}$} & \multirow{2}{*}{\begin{tabular}{|l}
$485,000 \mathrm{~m}^{2}$ \\
$46,000 \mathrm{~m}^{2}$
\end{tabular}} \\
\hline & & \\
\hline 従業員 数 & & 562 人 \\
\hline パル プ & 自製パルプ能力 & $660 \mathrm{~T} / \mathrm{D}$ \\
\hline 抄 紙 機 & 5 台能力合計 & $757 \mathrm{~T} / \mathrm{D}$ \\
\hline 塗 工 機 & 4 台能力合計 & $45 \mathrm{~T} / \mathrm{D}$ \\
\hline \multirow{2}{*}{ 電 } & $\begin{array}{l}\text { 夕ービン発電機, } 4 \text { 基設 } \\
\text { 備能力 }\end{array}$ & $38,000 \mathrm{~kW}$ \\
\hline & 購入電力 認叮最大 & $24,000 \mathrm{~kW}$ \\
\hline 水 & 取水河川 ( 2 河川) 取水量 & $144,000 \mathrm{~T} / \mathrm{D}$ \\
\hline 原料使用量 & チップ使用量 & $1,220 \mathrm{~T} / \mathrm{D}$ \\
\hline 紙生産高 & & $757 \mathrm{~T} / \mathrm{D}$ \\
\hline
\end{tabular}




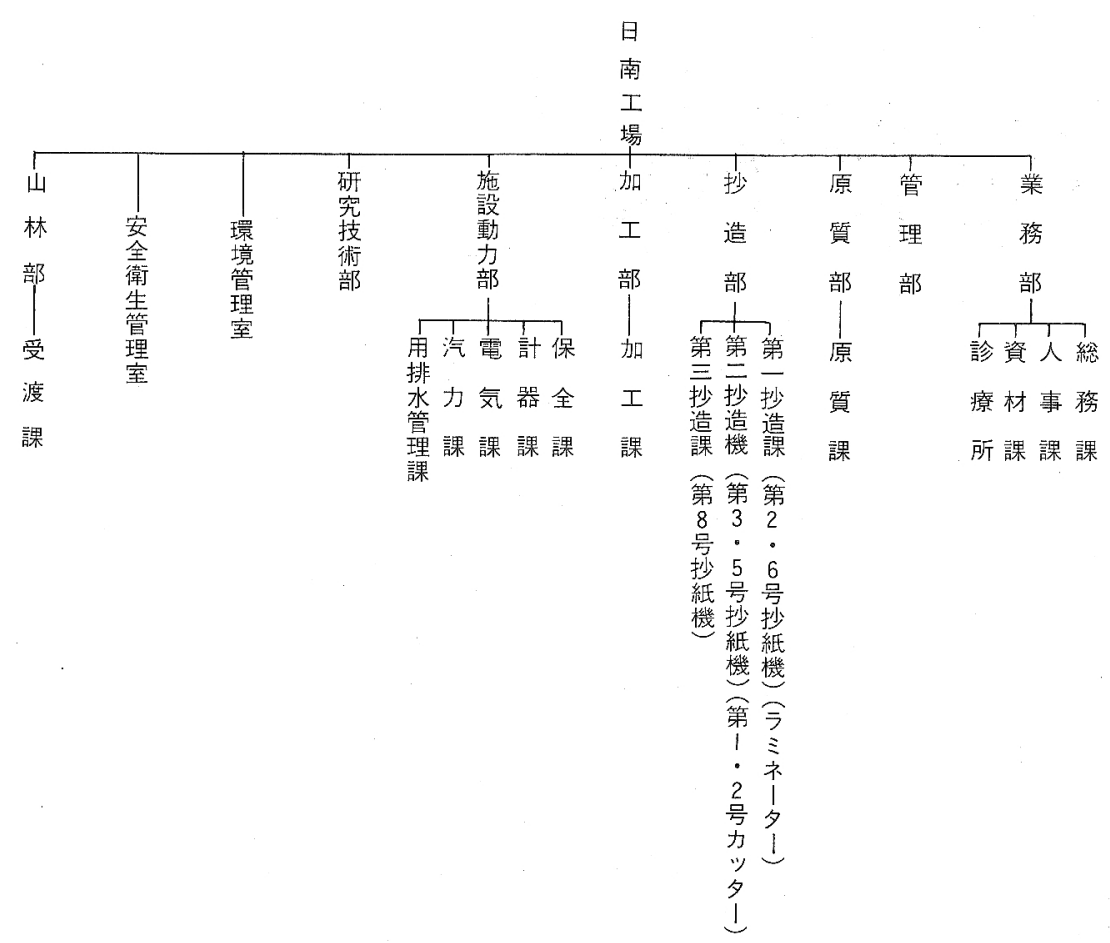

図2 日南工場組織図

表 3 Lチップの内訳

\begin{tabular}{c|l|l}
\hline 国内材チップ & $45 \%$ & 南九州 \\
\hline 外材チップ & $55 \%$ & \\
ユーカリ & 25 & 中 \\
オーク & 15 & アメリカ \\
ビーチ他 & 15 & チリ 他 \\
\hline
\end{tabular}

\section{・輸入チップ受入設備}

昭和 52 年 5 月に鹿児島県志布志港水深 $10 \mathrm{~m}$ バー スに隣接して $16,000 \mathrm{~m}^{2}$ のヤードを設け，チップ専用 船よりの荷揚げは移動式ホッパー，ベルトコンベヤ， 高架走行式トリッパー付ベルトコンベヤで行っている。 公害防止のために $12 \mathrm{~m}$ 高さのフェンス，コンべヤへ の水スプレイ, チップパイルへのシャワー, 全密閉式 ベルトコンベヤ，テレスコープ式シュート，排水ピッ 卜等を備えている。工場へは移動式積込コンベヤで払 出し, $15 \mathrm{t}$ トレーラー 17 台 $\times 3 \sim 4$ 往復でピストン輸 送している。

小型船は油津港水深 $7.5 \mathrm{~m}$ バースで移動式コンベ アを使って荷揚げし，トラックで工場へピストン輸送 している(写真 1$)$ 。

・工場チップ受払設備

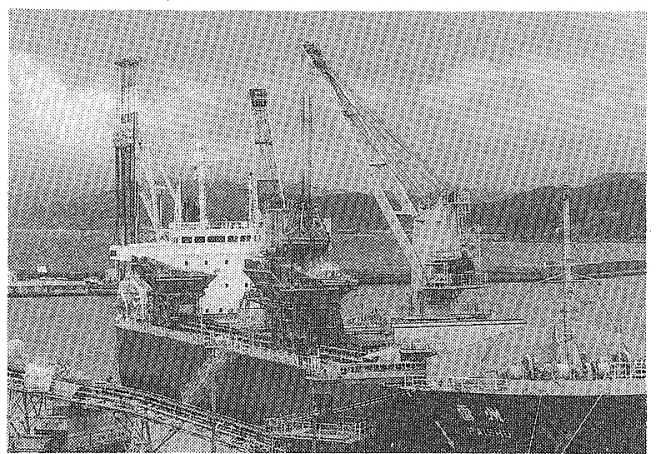

写真 1 油津港におけるチップ荷揚

輸入チップは志布志および油津港から，国内材チッ プは24カ所のチップ工場から夫々トラックで輸送し 構内に入ると重量検収して，3 台のトラックダンパー で各ヤードにコンベヤで受入れる。ヤード面積は合計 $24,000 \mathrm{~m}^{2}$ であり, サイロ系列に合わせて 2 系列に分 けている。ヤードからチップサイロまでの払出コンベ ヤの能力は $180 \mathrm{BDT} /$ 時である(写真 2 )。

\section{2 蒸解・洗浄・酸素徆・スクリーン工程}

- 蒸解・洗浄

連続蒸解鉒は気相液相式カミヤ連続釜でハイヒート 洗浄ゾーン 90 分を有している。パルプはディフュー 


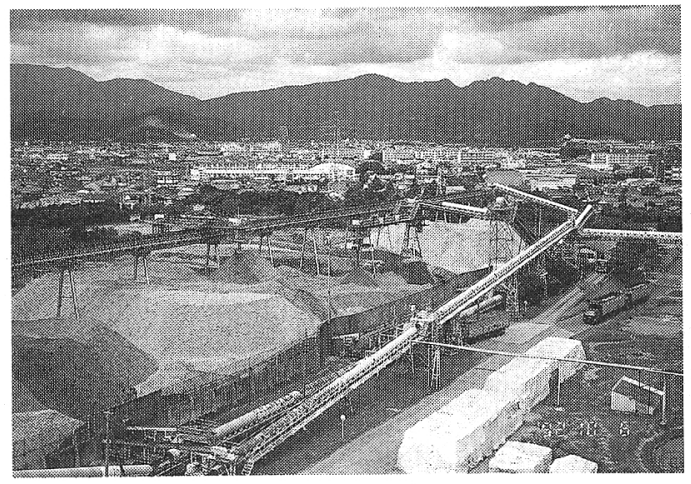

写真 2 構内チップヤード

ジョンウォッシャー, PRノッターを経て 3 系列のカ ミヤ式 2 段ドラムウォッシャーで洗浄し酸素晒設備へ 送っている。

\section{・酸素晒}

酸素晒設備は平成 3 年末に稼動し，プレリアクター

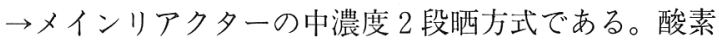
晒前の洗浄はカミヤアウターダブルサクションフィル ター2 段, 徆後の洗浄は DP プレスと前段と同型の フィルターの2 段で行っている。酸素晒に使用するア ルカリは白液を酸化して使用している（写真 3 ）。

・未晒スクリーン

未晒スクリーンは 2 系列ありそれぞれ 1 次コーワ ン+ 2 次コーワンの 2 段スクリーニングで, 洗原質は デッカーで脱水し未晒チェストへ送っている。

・眖スクリーン

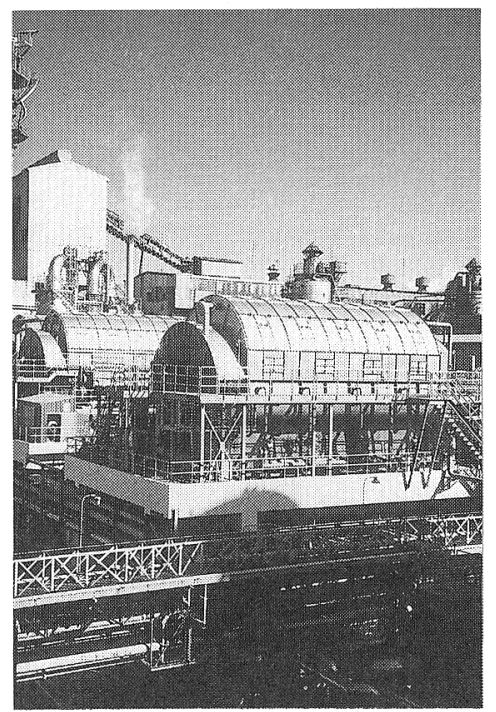

写真 3 酸素晒設備
晒スクリーンは 2 系列ありそれぞれコーワンとラジ クロンの 3 段で処理する。ラジクロンのリジェクトは ボージェクトタイプのアフタースクリーン 2 段で処理 し，良質纎維を回収している。アクセプトはデッカー で脱水し完成チェストへ送っている。

\section{3 薬品回収工程}

$$
\text { ・エバポレーター }
$$

連鉒からの抽出希黑液は 1,2 次フラッシュサイクロ ン及び 2 段のプレエバポレーターで濃縮し, マロン フィルターを通過後希黑液タンクに貯える。エバポ レーターは 9 缶 6 重効用のロスコ型エバポレーターで (写真 4 )，75\%まで濃縮し濃黑液タンクを経て回収ボ イラーに送っている。

・苛性化

緑液はクラリファイヤーで清澄化後苛性化工程へ送 り, ドレッグスはウォッシャーで洗浄し, 塩素処理排 液の中和に用いている。

苛性化工程は 2 系列ありスレーカー十荻性化槽十ク ラリファイヤーの組合わせである。両系は合流して白 液タンクに貯える。スラッジはスラッジウォッシャー 2 段で洗浄し， 2 基のキルン (フラッシュドライヤー 付）で燒成している。

薬品の補給は主に酸素晒で使用寸る苛性ソーダで行 い，石灰分は生石灰で補給している。

\section{4 漂白工程}

・漂白工程

漂白工程は 2 系列あり，両系ともほぼ同一である。

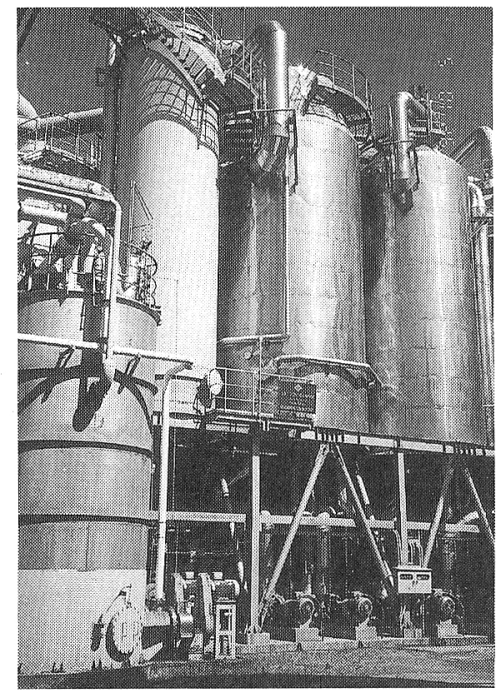

写真 4 ロスコエバポレーターと臭 気排水ストリッパー(手前) 
表 4 蒸解・洗浄・酸素晒主要設備

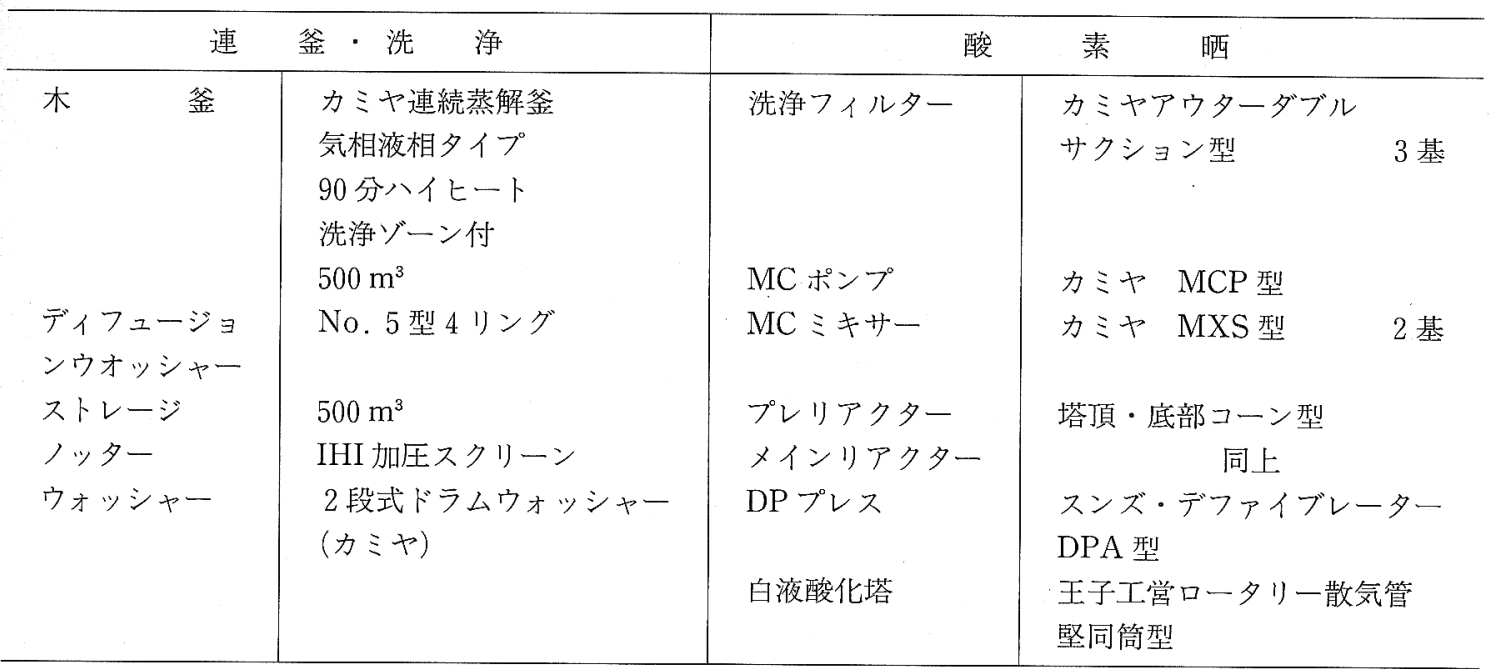

塩素処理は残塩素計と白色度計を用いた制御を行って いる。シーケンスは CEHDの 4 段晒である。また省工 ネルギーのため各フィルターの洗浄シャワー水には, パルプ工程から得られる中温水と高温水とを使い分け て使用し生蒸気は殆ど使用していない。

二酸化塩素発生設備は R-2 法で, 廃液はエバポレー ターに回収しているため硫黄バランス上塩酸法を採用 している。ソーダハイポは二酸化塩素の副生塩素と液 塩タンク排ガスを苛性ソーダに吸収させて粗ハイポと し，これに塩素を吹込んで仕上げている。 ・パルプマシン

生産バランス上の一時ストックとして, 若干のパル プを 100 インチカミールマシンで抄取っている。抄上 パルプは坪量コンベや，包装機，針金掛け機を経て一 時保管する。能力は $80 \mathrm{t} /$ 日, 水分 $50 \%$ のウェットシー トである。

\section{5 調成工程}

原料パルプはほとんどがLパルプで，抄物によって 若干のNシートを溶解し使用している。

Lの吒解にはデラックスファイナー, ダブルディス クリファイナー (DDR) を, N の吒解にはストックメー カー, クラフリン，およびデラックスファイナーを使 用している。ドライ損紙はパルパーで離解後, ハイド ラフレーカー, トップファイナーで精砕している。白 水回収設備にはセットラーとアドカを使用している。

\section{6 抄紙工程}

ペーパーマシンは 2 号から 8 号まで 5 台 $(4$ 号, 7 号 欠）ありすずて長網多筒式マシンで，それぞれのペー パーマシンに適したすき物を先取りし，残りを一般上
質紙に割り振っている。その中で 6 号マシンは小幅低 速マシンの特徴を生かし, 高付加価值特殊紙を抄造し ている。3号マシンは平成 2 年に增速工事を行い，地 合, プロファイルの良好な印刷用紙を生産している。 8 号マシンは 2 号 6 号マシンから離れた工場敷地に 建設されて扔り,昭和 53 年より上級紙用長網マシンと して最高スピード，高品質な生産を継続し，近年では PPC 用紙を長網マシンとしては最高スピードで生産 する当工場の主力マシンである。

サイズプレスを全マシンに設䈯してオフセット印刷 適性の向上に努め, プロコン化も積極的に推進し, BM 制御，灰分制御，自動紙替並びに抄速变更制御を行っ ている。カレンダーには誘電加熱式紙厚調整装置を採 用して，幅方向の紙厚制御を行うとともに，陥検出 器, カラーセンサーも導入している。また高速マシン はエアクッション型ヘッドボックスをハイドロリック

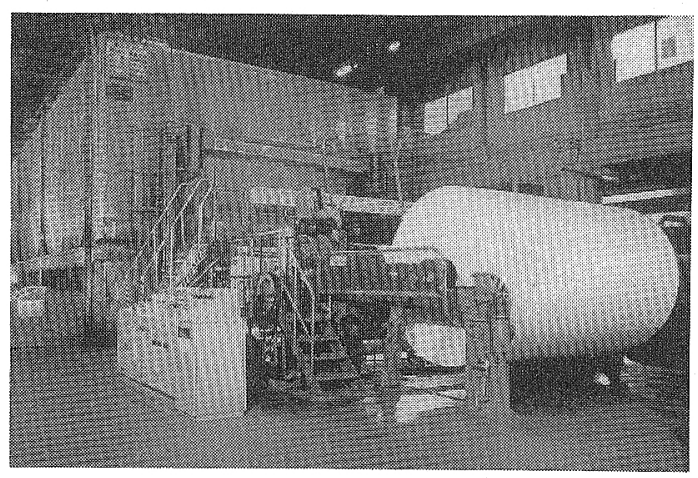

写真 58 号抄紙機 
表 5 抄紙機り久ト

\begin{tabular}{c|l|c|c|l|l}
\hline $\begin{array}{l}\text { M/C } \\
\text { No. }\end{array}$ & 形 式 & $\begin{array}{c}\text { 網 幅 } \\
(\mathrm{mm})\end{array}$ & $\begin{array}{c}\text { 日産能力 } \\
(\mathrm{t} / \text { 日) }\end{array}$ & \multicolumn{1}{|c|}{ 主 な 製 品 } & 稼働年月 \\
\hline 2 & 長網多筒 & 3,930 & 129 & 一般紙中厚物 & 昭 $31-3$ \\
3 & 長網多筒 & 3,950 & 205 & 一般紙中厚物, 書籍用紙, 加工原紙 & 昭 $35-3$ \\
5 & 長網多筒 & 3,810 & 111 & 一般紙薄物, 加工原紙 & 昭 $42-3$ \\
6 & 長網多筒 & 2,900 & 65 & 特殊 & 紙 \\
8 & 長網多筒 & 3,860 & 247 & 一般紙, PPC 用紙 & 昭 $52-12$ \\
\hline
\end{tabular}

型に更新して地合改善を図っている（表 5, 写真 5 )。

\section{7 仕上工程}

製品の仕上形態は，平判と巻取製品比率が約 $7: 3$ で ある。各ペーパーマシンにはそれぞれ専用のワイン ダーがあり，巻取製品は巻取包装機で包装し出荷寸る。 平判製品はワインダーで巻取られ自動倉庫を経由した 後に，平成 2 年に設置した生産効率が高く寸法精度に 優れた 2 台の高性能カッターで平判に断裁して, 平判 包装機で包装した後出荷する（写真 6 ）。

また, 小判製品系列は 4 台の小判カッターで断裁し, 包装機で包装しカートンケーサーで相包して出荷する。

\section{8 加工紙工程}

昭和 47 年に工場構内に加工紙工場を設置し,電子写 真紙の生産を開始して以来，情報産業用紙を主体とし

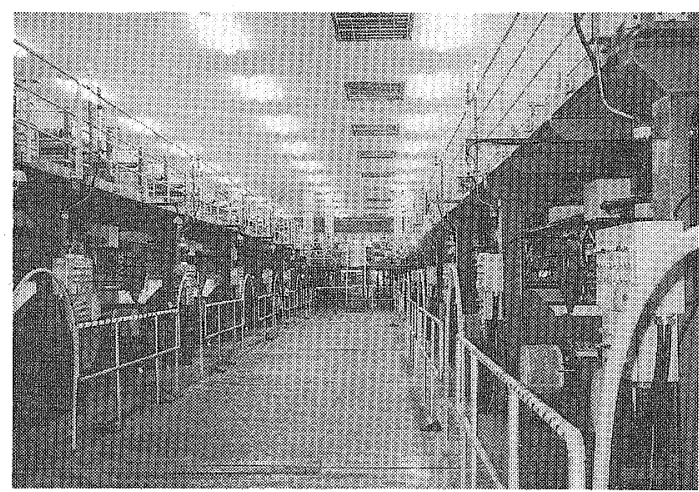

写真 6 シンクロフライカッター
た加工紙の生産を行っている。コーターは油系が塗工 出来るコーター及び水系専用コーターで，これに対応 するカラー設備を有している。コーターヘッドはエア ナイフをはじ,, 種々のタイプを有し塗工量は $1 \mathrm{~g} / \mathrm{m}^{2}$ から $30 \mathrm{~g} / \mathrm{m}^{2}$ で, 塗工も水系, 油系の多段の付加洒值 の高いものが多い。溶郕はゾルボマート回収装置で回 収し再使用している。

製品は複写, 複製, 通信と情報産業全般の多岐にわ たっており，大巻ロール，小巻ロール，小判シートの 出荷形態がある。原紙は極く一部の特殊原紙を除きほ とんどを抄造部からの一貫生産で賄っている（表 6， 写真 7)。

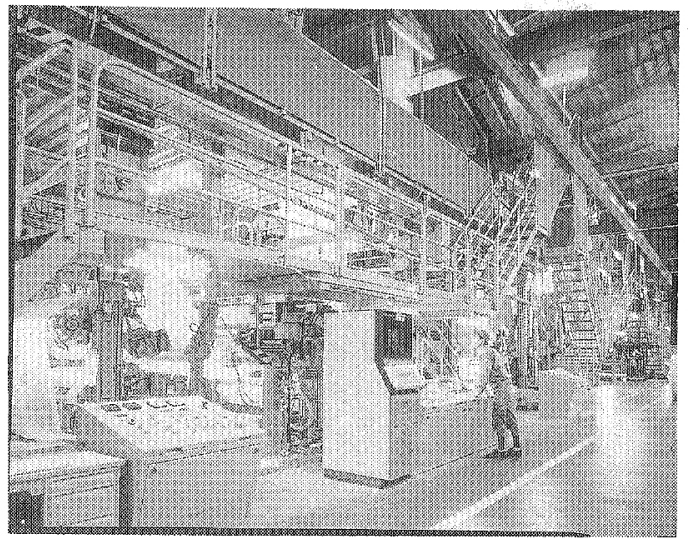

写真 74 号コーター

表 6 塗工㙨りス卜

\begin{tabular}{|c|c|c|c|c|}
\hline $\begin{array}{l}\mathrm{C} / \mathrm{M} \\
\mathrm{No}\end{array}$ & 形 & $\begin{array}{c}(\mathrm{mm}) \\
\text {-幅 }\end{array}$ & 主な & 稼働年月 \\
\hline 1 & オフマシンコーター & 1,600 & オフセットマスター, 静電記録紙 & 昭 $47-$ \\
\hline 2 & オフマシンコーター & 1,165 & オフセットマスター, 感熱記録紙 & 49 移設 \\
\hline 3 & オフマシンコーター & 1,600 & 感熱記録紙，静電記録紙 & 昭 $57-6$ \\
\hline 4 & オフマシンコーター & 1,600 & 感熱記録紙 ： ～～～～～～ & 平成元一 8 \\
\hline
\end{tabular}




\section{9 動 カ工程}

- 汽力

バークボイラー (BB) 1 基, 回収ボイラー (RB) 3 基, 重油ボイラー $(\mathrm{OB}) 1$ 基を有する。 $\mathrm{BB}$ は重油バー ク混焼ボイラーであるが，現在は排水処理スラッジ， バークと排夕イヤを混焼している。 RB はラージエコ タイプの $1 \mathrm{RB}$ とカスケド付 4,5 RB が設置されてい るが, 常用は $1 \mathrm{RB}$ のである。このボイラーは高温高 压タイプで, トップタービンに高圧蒸気を供給してい る。

$\mathrm{OB}$ は年間を通じ休止中で, 平常は $1 \mathrm{RB} と \mathrm{BB} の$ 運 転であり，主压制御に種々の工夫をしている。また発 電出力の時間带調整を回収ボイラーで実施し, 100 ～65\%の負荷調整を実施中である。

平均的には工場全体で $190 \mathrm{~T} / \mathrm{H}$ の蒸気を使用して いるが, 約 $80 \%$ RB が負担している。

・電力

平均電力使用量は $32,000 \mathrm{~kW}$ であり,この所要電力
を供給するため表 8 のような自家発電設備を有してい る。発電量は昼夜で異なるが，ほぼ $85 \%$ 自家発電で 賄っている。

タービンは $110 \mathrm{~K}$ 系背圧 (トップ) タービンと， 62 $\mathrm{K}$ 系抽気背压夕ービンの組み合せになっており，増発 電を目的に背気蒸気で復水夕ービンを運転している。

自家発電電圧は $3,300 \mathrm{~V}$ であるが, $3 \mathrm{~T} / \mathrm{G}$ 発電のみ $11,000 \mathrm{~V}$ であるため, 発電所用变圧器 $20,000 \mathrm{kVA}$ を 設けている。

・用水

酒谷山の伏流水と広渡川の表面水をほぼ半々づつ 14 万 4 千 $\mathrm{m}^{3}$ /日 (取水権) の用水を使用している。ア クセレーター処理後は急速サンドろ過槽 32 槽を通し て処理している。

\subsection{0 環境保全関係}

昭和 47 年 4 月に宮崎県, 日南市, 工場の三者による 公害防止協定を締結し, 昭和 60 年, 平成 3 年と 2 度に わたり協定改訂を行い，最新設備の導入など公害防

表 7 汽 缶 設 備

\begin{tabular}{|c|c|c|c|c|c|}
\hline & $1 \mathrm{BB}$ & $1 \mathrm{RB}$ & $4 \mathrm{RB}$ & $5 \mathrm{RB}$ & $6 \mathrm{OB}$ \\
\hline 型 式 & $\mathrm{CE}$ バーク & $\mathrm{CE} 2$ 胴水管 & $\rightarrow$ & $\rightarrow$ & $\rightarrow$ \\
\hline 蒸発量 $\quad(\mathrm{t} / \mathrm{h})$ & 45 & 185 & 35 & 30 & 100 \\
\hline 常用压力 $\left(\mathrm{kg} / \mathrm{cm}^{2}\right)$ & 64 & 114 & 64 & $\rightarrow$ & $\rightarrow$ \\
\hline 通 風方式 & 平 衡 & $\rightarrow$ & $\rightarrow$ & $\rightarrow$ & 押 込 \\
\hline 一次集じん器 & マルチサイクロン & コットレル & コットレル & コットレル & - \\
\hline 二次集じん器 & コットレル & - & - & - & - \\
\hline 排 煙 脱 硫 & サイクロンスクラバー & - & - & - & - \\
\hline $\begin{array}{llll}\text { 設 } & \text { 置 } & \text { 年 }\end{array}$ & 昭 $35-6$ & 昭 $60-12$ & 昭 $41-5$ & 昭 $47-4$ & 昭 $47-4$ \\
\hline
\end{tabular}

表 8 発 電 設 備

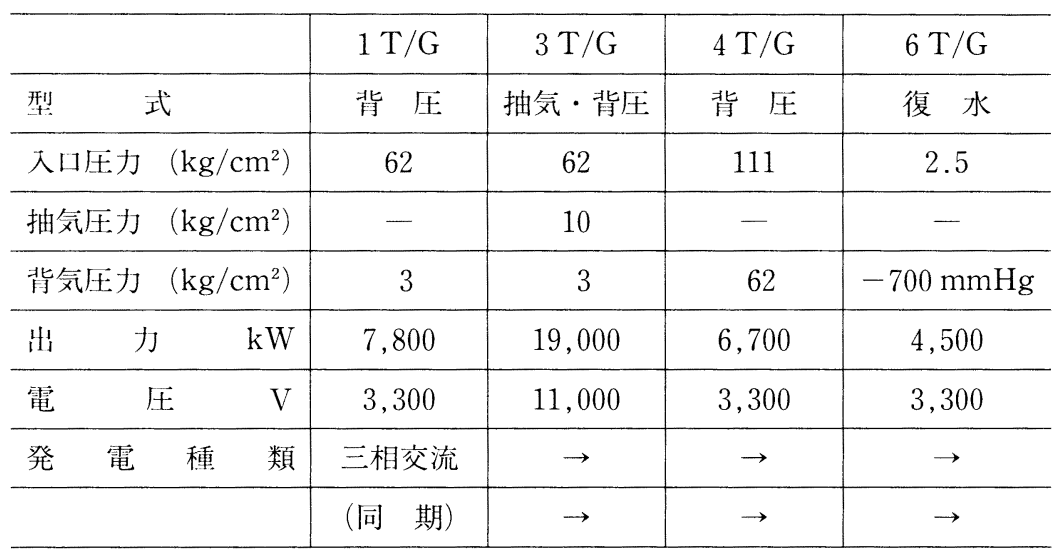


表 9 主要環境規制值

\begin{tabular}{|c|c|c|c|}
\hline & & 法規制值 & 協 定 值 \\
\hline 質 & $\begin{array}{ll}\mathrm{COD} & (\mathrm{mg} / \mathrm{l}) \\
\mathrm{SS} & (\mathrm{mg} / \mathrm{l}) \\
\mathrm{pH} & \\
\text { 色度 } & \text { (度) }\end{array}$ & $\begin{array}{c}120 \text { 以下 } \\
150 \text { 以下 } \\
5 \sim 9 \\
-\end{array}$ & $\begin{array}{r}90 \text { 以下 } \\
75 \text { 以下 } \\
5.5 \sim 8.5 \\
200 \text { 以下 }\end{array}$ \\
\hline $\mathrm{SO}_{\kappa}$ & $\mathrm{K}$ 值 & 17.5 & - \\
\hline $\begin{array}{l}\text { ばいじん } \\
\left(\mathrm{g} / \mathrm{Nm}^{3}\right)\end{array}$ & $\begin{array}{l}\mathrm{RB} \\
\mathrm{BB} \\
\mathrm{OB} \\
\text { キルン }\end{array}$ & $\begin{array}{l}0.15 \text { 以下 } \\
0.30 \text { 以下 } \\
0.18 \text { 以下 } \\
0.30 \text { 以下 }\end{array}$ & $\begin{array}{l}0.13 \text { 以下 } \\
0.25 \text { 以下 } \\
0.15 \text { 以下 } \\
0.25 \text { 以下 }\end{array}$ \\
\hline 悪 & 臭気強度 & - & 2.5 以下 \\
\hline
\end{tabular}

注） COD, SS，色度は日間平均值

止・環境保全対策に鋭意取組んでいる。当工場の規制 状況を表 9 に示す。

環境管理体制としては，環境管理室を設置して環境 保全状況の監視に当たると共に，環境改善対策を推進 するために工場長を委員長とする環境改善委員会を設 置している。

\section{・水質関係}

当工場の排水は以下の処理を行い, $3.2 \mathrm{~km}$ 先の海岸 に放流している。従って COD 規制を受けている。工場 排水を $\mathrm{A}$ (洋紙排水), B (パルプ洗浄, 漂白, エバポ レーター)に分け，A 排水は単純沈澱処理，B 排水は 一部活性污泥処理してから凝集沈港処理している。凝 集沈澱スラッジと活性污泥設備の余剩スラッジは脱水, 予備乾燥してバークボイラーで烧却している。

エバポレータードレン，連釜呬りドレン等は臭気排 水としてエアストリッパーに通し臭気がスを分離した 後, 活性污泥処理をしている。苛性化工程から出るド レッグスは晒塩素段排水の中和に用いている。

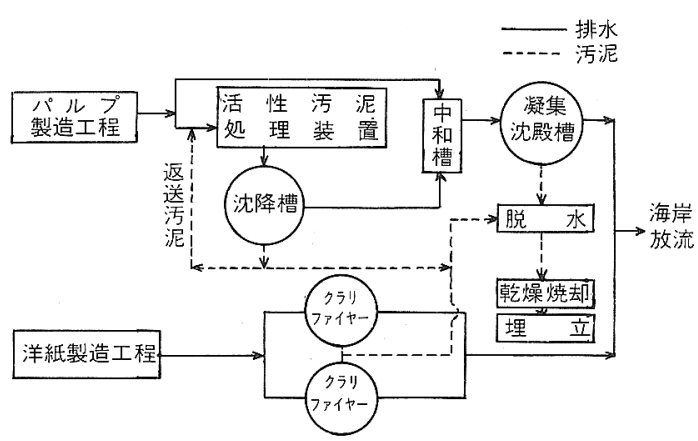

図 3 排水処理設備フローシート

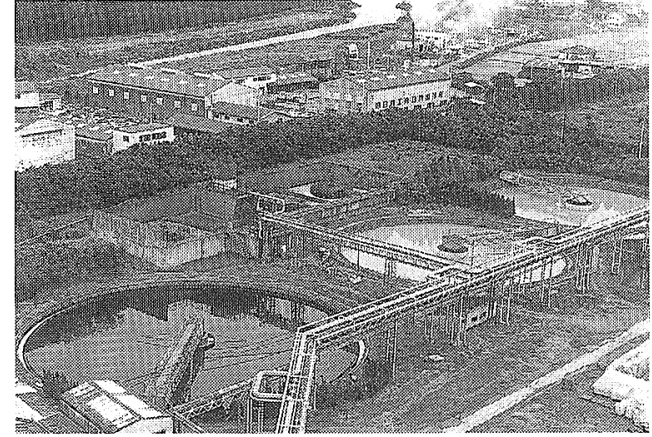

写真 8 排水処理設備

なお，当工場では海岸放流口に自動 COD 計を設置 し, 総合排水の COD 濃度を常時監視し污染防止に努 めている(図 3, 写真 8 )。

\section{-大気関係}

$\mathrm{SO}_{x}$ については規制值が $\mathrm{K}$ 值 17.5 であるが，低自 気型回収ボイラーを設置しており，またバークボイ ラーには排煙脱硫装置を設けているので全く問題のな いレベルである。なお，重油ボイラーは省工ネ対策を 積極的に進めて来な結果，通常時は運転していない。

汽缶の集じん設備については表 7 に揭げたように, $\mathrm{RB}$ では電気集じん器 $(\mathrm{E} / \mathrm{P})$ 方式, $\mathrm{BB}$ についてはマ ルチサイクロン $+\mathrm{E} / \mathrm{P}+$ 排煙脱硫装置付湿式スクラ バー, キルンはサイクロン+湿式 $\mathrm{E} / \mathrm{P}$ 方式をとってい る。

・臭気関係

連鉒, エバポレーターその他各工程から発生する臭 気ガスはすべて密封，吸引捕集し回収ボイラーで燃焼 している。すなわち臭気排水ストリッパー，ウォッ シャーフード, タンク類等の希薄臭気がスは連釜のフ ラッシュサイクロンとスチーミングベッセル，エバポ レーターから出る濃厚臭気がスの希釈に用い, 最終的

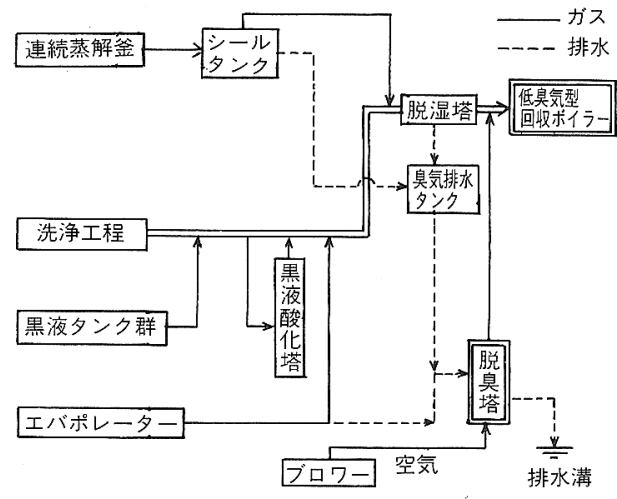

図 4 臭気ガス燃焼フローシート 


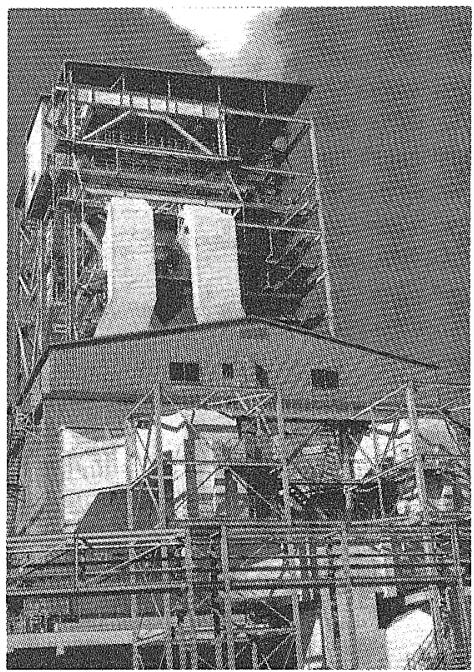

写真 91 号回収ボイラー

にはRB で燃焼している（図 4，写真 9）。

・㪃音

個々の発生源に消音器，防音囲い，防音壁等を設け て効果を発揮している。

・廃棄物

バークボイラーの焼却灰を中心に月間約 $1,000 \mathrm{t} の$ 廃棄物が発生している。このため管理型の自社最終処 分場を設置し埋立を行っている。

\subsection{1 物流関係}

製品用倉庫としては構内各所に $8,500 \mathrm{~m}^{2}$, 油津港に $3,200 \mathrm{~m}^{2}$ を有している。資材関係は倉庫 $6,800 \mathrm{~m}^{2}$, 夕 ンク $4,200 \mathrm{~m}^{3}$ ，その他野積場等を有している。

また, 油津港, 志布志港, 宮崎港, 細島港等の海路, および国道による陸道が当工場の物流手段であるが, 原木，資材，製品に扔ける船輸送比率は極めて高い。

\section{5. 乥の他}

\section{1 設 備 保 全}

当工場の設備保全は施設動力部が担当している。保 全部門は機械設備の点検保守を担当する保全課, 制御 系を含む電気設備の保守を担当する電気課, 更にプロ セスコンピューター制御を始好する各種計器の保守
を担当する計器課からなり，それぞれ専門の保全員に 依る集中保全方式に依って設備の保全を実施している。 設備保全に対する考え方は子防保全をべースとし， より故障の少ない設備作りを目指した改良保全，保全 予防を行っている。また近年は機器診断に依る予知保 全も加わり総合的な生産保全に移行して来ている。

\section{2 安全・衛生・防火・防災}

安全・衛生の管理には特に力を入れ，安全衛生管理 室を設けて協力会社を含妨取組みを実施している。 特に協力会社と工場の施設部門並びに運転部門との接 点には力を入れている。

防火に関しては各職場より成る防火専門委員会を設 け，常時パトロールとチェックを行い，定期的に夜間 消防訓練を含めた工場レベルの訓練を実施している。

\section{6. 主な関連会社}

\section{1 日南王子紙業(侏)}

昭和 55 年に当社の仕上げ部門が独立して設立され た。当社で生産する上質紙, 特殊紙, 加工紙の断裁, 選別, 包装, 構内倉庫, 運搬作業等工場生産ラインの 最終仕上工程を受け持っている。従業員 310 名。主な 設備は下記の通りである。

$\begin{array}{ll}\text { 平判カッター } & 2 \text { 台 } \\ \text { 平判自動包装ライン } & 2 \text { 系列 } \\ \text { 小判カッター及び自動包装ライン } & 4 \text { 系列 } \\ \text { リワインダー, スリッター } & 8 \text { 台 } \\ \text { 巻取り包装機 } & 2 \text { 台 他 }\end{array}$

\section{2 王子工営(侏)日南事業部}

当社を主体に紙パルプ産業設備の設計製作据え付け と保全工事を主な業務としている。特に精密機械の設 計製作の経験が豊富で, 自動化機械とコンピューター を含めた開発設計に力を入れており，その他，環境計 量測定業務等幅広く手掛けている。主な商品として下 記の設備他の実績を有する。

マシン坪量制御装置

(TET，マイクロロッド ASS システム)

平判自動給紙ロボット

$$
\text { (オートリームフィーダー) }
$$

マシン製品欠陥除去システム設備

(HS マーカー，リーダー) 


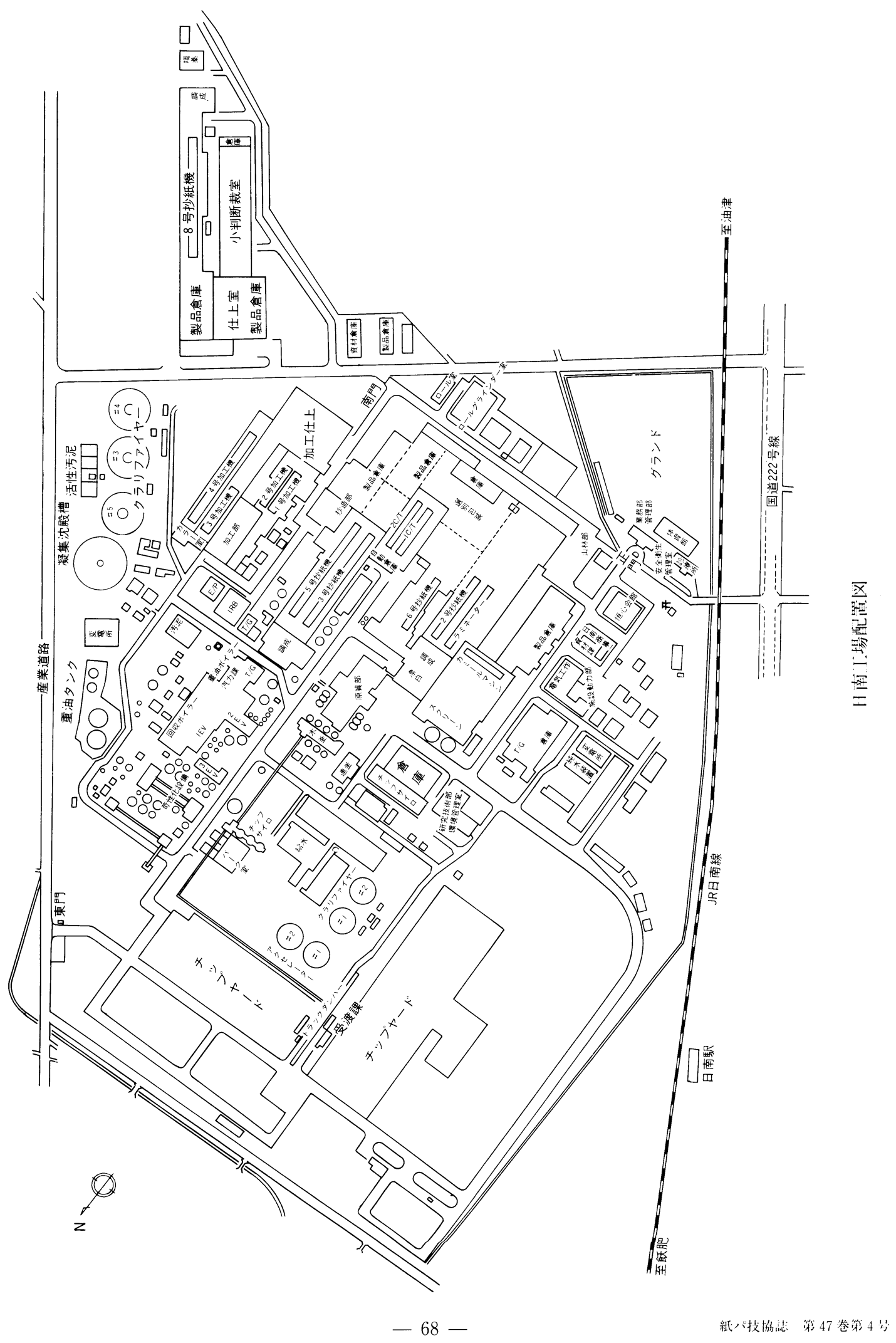

